\title{
DEPRESSIVE SYMPTOMS AND FUNCTIONALITY IN OLDER ADULTS OF THE PORTO ALEGRE'S PRIMARY CARE
}

\author{
Sintomas depressivos e funcionalidade em \\ idosos da atenção primária de Porto Alegre (RS)
}

\author{
Douglas Nunes Stahnke ${ }^{a}$ (D), Renata Breda Martins ${ }^{a}$ (D), Raquel Rousselet Farias ${ }^{a}$ (i),

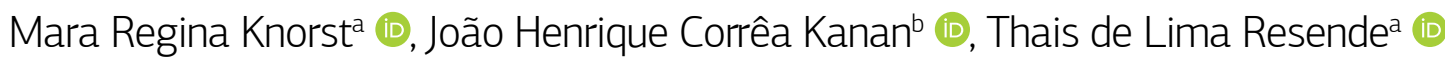

OBJECTIVE: The aim of this study was to determine the prevalence of depressive symptoms (DS) and their relationship with functional, sociodemographic and anthropometric aspects in the older adults from the Family Health Strategy of Porto Alegre/ RS. METHOD: This is a cross-sectional, prospective and analytical study, with a random sample of 509 older adults from 30 public health units. The following variables were analyzed: age, age group, sex, marital status, schooling, weight, height and $\vdash \quad$ body mass index, functionality, activities of daily living, both basic and instrumental, and the presence of DS. For the statistical $\varangle \quad$ analyses, the bivariate qui-square test and the multivariate logistic regression were used. RESULTS: The prevalence of DS in $\stackrel{\sim}{\leftarrow}$ this sample was 35,5\%. The final model presented a significant statistical association of DS with female gender (OR $=2.87$; u IC95\% 19.2-9.23), illiteracy (OR = 2.13; IC95\% 1.89-5.12), low schooling (OR = 1.23; IC95\% 1.05-2.74), dependence on IADL $\varangle \quad(O R=4.03$; IC95\% 1.68-9.64), low scores in the sit-to-stand test (OR = 0.89; IC95\% 0.82-0.96) and lower HCS (OR = 0.95; IC95\% 0.93-0.98). CONCLUSION: The prevalence of DS observed was high (35.4\%) and, considering the associations presented, it is suggested that illiterate or poorly educated, weaker and slower women with difficulty in IADL should be investigated for the presence of depressive symptoms, for being at the risk of developing them.

KEYWORDS: aged; walking speed; muscle strength; activities of daily living; Family Health Strategy.

OBJETIVO: Determinar a prevalência de sintomas depressivos (SD) e a sua relação com aspectos funcionais, sociodemográficos e antropométricos em idosos da Estratégia Saúde da Família de Porto Alegre (RS). MÉTODOS: Trata-se de um estudo transversal prospectivo e analítico com amostra aleatória de 509 idosos de 30 unidades básicas de saúde. Analisaram-se idade, faixa etária, sexo, estado civil, escolaridade, peso, altura, índice de massa corporal, funcionalidade, atividades básicas e instrumentais de vida diária e presença de SD. Para análise estatística, utilizou-se o teste $\chi^{2}$ (bivariada) e de regressão logística (multivariada). RESULTADOS: A prevalência de SD na amostra foi de 35,4\%. O modelo final apresentou associação estatisticamente significativa de SD com sexo feminino (odds ratio - OR = 2,87; intervalo de confiança de 95\% - IC95\% 1,92-9,23), analfabetismo [(OR = 2,13; IC95\% 1,89-5,12), baixa escolaridade (OR = 1,23; IC95\% 1,05-2,74), dependência em atividades instrumentais de vida diária (OR = 4,03; IC95\% 1,68-9,64), baixos escores no teste senta/levanta (OR = 0,89; IC95\% 0,82-0,96) e menor força de preensão manual (OR = 0,95; IC95\% 0,93-0,98). CONCLUSÃO: A prevalência dos SD observada foi alta, e, ante as associações apresentadas, sugere-se que mulheres analfabetas ou com baixa escolaridade, com dificuldade em atividades instrumentais de vida diária, mais fracas e lentas devem ser investigadas quanto à presença de SD, pelo risco de desenvolvê-los.

PALAVRAS-CHAVE: idoso; velocidade de caminhada; força muscular; atividades cotidianas; Estratégia Saúde da Família.

aSchool of Health and Life Sciences, Pontifícia Universidade Católica do Rio Grande do Sul - Porto Alegre (RS), Brazil. bInstitute of Basic Health Sciences, Department of Microbiology, Immunology and Parasitology, Universidade Federal do Rio Grande do Sul Porto Alegre (RS), Brazil.

Corresponding address

Thais de Lima Resende - Escola de Ciências da Saúde e da Vida, Pontifícia Universidade Católica do Rio Grande do Sul - Avenida Ipiranga, 6.681, Prédio 81 - 60 andar - sala 603 - Partenon - CEP: 90619900 - Porto Alegre (RS), Brazil. E-mail: thaislr@pucrs.br

Received on: 10/03/2019. Accepted on: 11/14/2019

DOI: 10.5327/Z2447-212320201900071 


\section{INTRODUCTION}

The rapid demographic growth of people aged 60 years and over has been the subject of studies in Brazil and around the world, largely due to the high financial impact on social and public health policies, which require adjustments to provide adequate care for this population. ${ }^{1,2}$

In addition to the accelerated growth of the older population in the country, it is necessary to consider that $6.8 \%$ of them report difficulties in performing some activities of daily living without assistance. ${ }^{3}$ In this setting, there is a need for health policies and strategies to improve autonomy and quality of life in older adults, as biological aging can bring about cognitive and motor changes that sometimes make this population dependent and modify their lifestyle. ${ }^{4,5}$ The cognitive and functional disability in aging adults can be reflected in psychological distress and decreased social participation. ${ }^{6,7}$ In this context, depression is the most important causative agent of reduced quality of life in older people in emerging countries. ${ }^{8}$ Additionally, it is the second most important factor that impairs functional capacity in older adults in developed countries, ${ }^{8}$ representing a significant public health problem in Brazil, where the prevalence in the older population ranges from 4.7 to $36.8 \% .^{5}$

In this clinical and epidemiological context, the present study was developed to determine the relationship between depressive symptoms (DS) and functional, sociodemographic, and anthropometric aspects in older adults attending the Family Health Strategy (FHS) in Porto Alegre, state of Rio Grande do Sul.

\section{METHODS}

From March 2011 to December 2012, a study called 'The multidimensional study of the older people in the Family Health Strategy in Porto Alegre, Brazil (EMISUS)' was developed, with a cross-sectional and analytical design. The investigation involved 30 FHS teams, randomly selected from each health district, around $30 \%$ from each district. Each FHS participating in the study provided a list of older adults registered by their teams. Then, 36 of them were randomly selected from each of the participating FHS teams to participate in this research. ${ }^{9}$ All randomization (teams and older users) was performed by random number tables generated in the Excel software.

Sample

A total of 587 older adults were evaluated in 2 stages:
- Collection of general data, including interviews conducted by community health care agents in the participants' homes to obtain information on sociodemographic and clinical aspects;

- Clinical evaluation, by a multidisciplinary team at the Hospital São Lucas (HSL), of the Pontifícia Universidade Católica do Rio Grande do Sul (PUCRS). ${ }^{9}$

Inclusion criteria were: age 60 years or over and active registration in the FHS. Individuals unable to go to HSL for the multiprofessional evaluation were excluded. This exclusion was minor, because the research group provided transportation for participants, who were picked up at their FHS units or at their dwellings, if they could not get there without help.

\section{Measurement and evaluation instruments}

The variables studied, their categories, the evaluation instrument used and the place of collection are shown in detail in Table 1. For the analysis of the present study, the following variables of the original sample were used: sex, age, age range, marital status, education, weight, height, body mass index (BMI), ${ }^{10}$ sit-to-stand score,${ }^{11}$ handgrip strength (HGS), ${ }^{12}$ time (seconds) to walk $10 \mathrm{~m},{ }^{13}$ basic activities of daily living (ADLs - Katz Index), ${ }^{14}$ instrumental activities of daily life (IADLs - Pfeffer's scale) ${ }^{15}$ and presence of DS (short version of the Geriatric Depression Scale - GDS-15). ${ }^{16}$

\section{Statistical analysis}

Data were analyzed using SPSS version 20.0 (SPSS Inc., Chicago, IL, United States), and significance was established at $5 \%$.

The Kolmogorov-Smirnov test was used to determine the continuous variables' distribution, while Student's $t$-test and Mann-Whitney's test were used in the comparison between 2 independent groups. Pearson's $\chi^{2}$ test with continuity correction or Fisher's exact test were used in the bivariate analysis between categorical variables. To estimate the effect measure, the crude odds ratio (OR) was used, with a $95 \%$ confidence interval $[\mathrm{CI}]$.

For multivariate analysis, the logistic regression of the variables with $p$ values $<0.200$ in the bivariate analysis was performed using the backward conditional method on the saturated model. The association was assessed with the likelihood-ratio test (2LL or $-2 \log$ ) and the quality of fit of the final logistic regression model with the Nagelkerke and Hosmer-Lemeshow $\mathrm{R}^{2}$ estimators. The probability of gradual entry of the variables to the model was 0.05 and for removal, 0.10 , and the cutoff point for statistical significance 
was established at 0.50 for a maximum of 20 interactions. Significance levels below 0.01 were considered significant based on the Bonferroni criterion.

\section{Ethical Considerations}

Both the Research Ethics Committee of PUCRS and that of the Municipal Health Secretariat of Porto Alegre approved the project (approval certificate numbers 10/04967 and 001.021434.10.7, respectively), in compliance with the Research Regulatory Guidelines and Standards of Resolution n. 196/96 of the Brazilian National Health Council of the Ministry of Health (CNS / MS). All participants and / or their guardians were clearly informed about the objectives and methods of the research and provided written information consent, of which they received a copy.

\section{RESULTS}

The original sample included 587 people, however the data from 78 participants (13.3\%) were disregarded, due to missing data in relation to the variable DS. Thus, the results refer to a sample of 509 participants (Table 2), of which $35.4 \%$ presented DS, most of them women up to 69 years, who did not live with a partner, and presented a low level of education as well as overweight/obesity.

The results regarding the associations found between DS and the sociodemographic characteristics of the sample are shown in Table 2, while Table 3 shows the results concerning functional and clinical characteristics, and Table 4 indicates the predictive factors for the occurrence of DS - both the initial (saturated) and the final (reduced) models, established in 6 stages. Due to the loss of the predictive potential

Table 1 Description of the study variables: categories, instruments used and places of collection.

\begin{tabular}{|c|c|c|c|c|}
\hline \multirow{2}{*}{ Type of Variable } & \multirow{2}{*}{ Variables } & \multirow{2}{*}{ Categories } & \multicolumn{2}{|c|}{ Data Collection } \\
\hline & & & Instrument & Place \\
\hline \multirow{4}{*}{ Sociodemographic } & Age & No & $\begin{array}{l}\text { Global Assessment } \\
\text { questionnaire for the } \\
\text { older population }\end{array}$ & Home \\
\hline & Age range & $\begin{array}{l}60 \text { to } 69 \text { years; } 70 \text { to } \\
79 \text { years; } \geq 80 \text { years }\end{array}$ & $\begin{array}{l}\text { Global Assessment } \\
\text { questionnaire for the } \\
\text { older population }\end{array}$ & Home \\
\hline & Education level & $\begin{array}{l}\text { illiterate; low; medium + } \\
\text { high schooling }\end{array}$ & $\begin{array}{l}\text { Global Assessment } \\
\text { questionnaire for the } \\
\text { older population }\end{array}$ & Home \\
\hline & Marital status & $\begin{array}{l}\text { Marital cohabitation; does } \\
\text { not live with a partner }\end{array}$ & $\begin{array}{l}\text { Global Assessment } \\
\text { questionnaire for the } \\
\text { older population }\end{array}$ & Home \\
\hline \multirow{3}{*}{ Anthropometrical } & Weight & No & Welmy scale ${ }^{\hat{a}}$ & HSL \\
\hline & Height & No & Measuring Tape & HSL \\
\hline & BMI & $\begin{array}{l}\text { Low weight; eutrophy; } \\
\text { overweight/obesity }\end{array}$ & $\begin{array}{c}\text { Quetelet } \\
(\text { BMI }=\text { weight } / \text { height })^{2}\end{array}$ & HSL \\
\hline \multirow{5}{*}{ Functional } & Time to walk $10 \mathrm{~m}$ & No & Chronometer & HSL \\
\hline & $\begin{array}{c}\text { 30-second } \\
\text { sit-to-stand test } \\
\text { (no. repetitions/30s) }\end{array}$ & No & Chronometer & HSL \\
\hline & Handgrip strength (kgf) & No & Crow $^{\circ}$ Dynamometer & HSL \\
\hline & ADLs & $\begin{array}{l}\text { Independent (Katz } \geq 5) \text {; } \\
\text { dependent }(\text { Katz } \leq 4)\end{array}$ & Katz Index & HSL \\
\hline & IADLs & $\begin{array}{l}\text { Independent }(\text { Pfeffer } \leq 4) \\
\text { dependent }(\text { Pfeffer } \geq 5)\end{array}$ & Pfeffer's scale & HSL \\
\hline Clinical & DS & $\begin{array}{l}\text { With DS (GDS-15 } \geq 5 \text { ); } \\
\text { without DS (GDS-15 < 5) }\end{array}$ & $\begin{array}{c}\text { Geriatric Depression } \\
\text { Scale - short version } \\
\text { (GDS-15) }\end{array}$ & HSL \\
\hline
\end{tabular}

HSL: Hospital São Lucas at the Pontifícia Universidade Católica do Rio Grande do Sul; BMI: body mass index; ADLs: Basic Activities of Daily Living; IADLs: Instrumental Activities of Daily Living; Katz: Katz Index score; Pfeffer: Pfeffer's scale score; DS: depressive symptoms; GDS-15: score obtained on the Geriatric Depression Scale (GDS) - short version. 
of certain variables, the final model consisted of 6 variables (Table 4): female sex, illiteracy, education level, dependence on IADLs, lower sit-to-stand test scores, and lower HGS.

The Hosmer-Lemeshow test indicated that there were no significant differences between the model estimates and the actual sample classifications for the presence of DS $(\chi 2=6.866 ; p=0.388)$. In this sense, the confusion matrix for the total number of correct answers was $64.2 \%$, in which the model correctly classified $55.6 \%$ of the cases without DS and $72.4 \%$ of the cases that confirmed the presence of DS.

\section{DISCUSSION}

The profile of the sample - a majority of women aged 60-69 years and with low level of education - reveals that it is similar to that of the research universe, i.e., the older population in the city of Porto Alegre. ${ }^{17}$ However, there is a disagreement regarding marital coexistence, because, according to data from the Porto Alegre Municipal Plan for older adults, $26.5 \%$ of inhabitants aged 60-69 live with a partner, while in the present sample this rate was higher, $36.9 \% .{ }^{17}$

Two known risk factors for the presence of DS were confirmed, female sex and illiteracy. ${ }^{18}$ Women were more likely to

Table 2 Sociodemographic characteristics of the sample, according to the presence of depressive symptoms.

\begin{tabular}{|c|c|c|c|c|c|c|}
\hline \multirow{2}{*}{ Variables } & \multicolumn{5}{|c|}{ Depressive Symptoms } & \multirow{2}{*}{$\begin{array}{l}\text { Odds Ratio } \\
(95 \% \mathrm{Cl})\end{array}$} \\
\hline & \multicolumn{2}{|c|}{ Yes $(n=180)$} & \multicolumn{2}{|c|}{ No $(n=329)$} & $\mathbf{p}^{E}$ & \\
\hline \multicolumn{7}{|l|}{ Sex* } \\
\hline Men & 45 & 25.0 & 129 & 39.2 & \multirow{2}{*}{$0.001^{\S}$} & 1.0 \\
\hline Women & 135 & 75.0 & 200 & 60.8 & & $1.24(1.10-1.40)$ \\
\hline \multicolumn{7}{|l|}{ Age (years) } \\
\hline Mean \pm SD (Range) & \multicolumn{2}{|c|}{$68.9 \pm 7.6(60.0-100.2)$} & \multicolumn{2}{|c|}{$68.7 \pm 6.8(60.0-103.8)$} & $0.749^{\epsilon}$ & $1.04(0.97-1.03)$ \\
\hline \multicolumn{7}{|l|}{ Age range* } \\
\hline Up to 69 years & 114 & 63.3 & 210 & 63.8 & \multirow{3}{*}{$0.873^{\S}$} & 1.0 \\
\hline $70-79$ years & 50 & 27.8 & 94 & 28.6 & & $0.98(0.64-1.48)$ \\
\hline 80 years or over & 16 & 8.9 & 25 & 7.6 & & $1.18(0.60-2.30)$ \\
\hline \multicolumn{7}{|l|}{ Marital status* } \\
\hline Marital Cohabitation & 70 & 38.9 & 118 & 35.9 & \multirow{2}{*}{$0.499^{\S}$} & $1.08(0.85-1.38)$ \\
\hline Does not live with a partner & 110 & 61.1 & 211 & 64.1 & & 1.0 \\
\hline \multicolumn{7}{|l|}{ Schooling* } \\
\hline Illiterate & 61 & 33.9 & 59 & 17.9 & \multirow{3}{*}{$<0.001^{\S}$} & $3.02(1.11-7.31)$ \\
\hline Low & 109 & 60.6 & 235 & 71.4 & & $1.11(0.79-2.83)$ \\
\hline Medium and high & 10 & 5.6 & 34 & 10.3 & & 1.0 \\
\hline \multicolumn{7}{|l|}{ Weight (kg) } \\
\hline Mean \pm SD (Range) & \multicolumn{2}{|c|}{$69.6 \pm 14.9(42.0-122.1)$} & \multicolumn{2}{|c|}{$70.7 \pm 13.5(32.5-113.3)$} & $0.437^{*}$ & $0.99(0.98-1.08)$ \\
\hline \multicolumn{7}{|l|}{ Height $(\mathrm{m})$} \\
\hline Mean \pm SD (Range) & \multicolumn{2}{|c|}{$1.54 \pm 0.08(1.32-1.77)$} & \multicolumn{2}{|c|}{$1.58 \pm 0.09(1.37-1.78)$} & $<0.001^{*}$ & $0.02(0.001-0.11)$ \\
\hline \multicolumn{7}{|l|}{ BMI $\left(\mathrm{kg} / \mathrm{m}^{2}\right)$} \\
\hline Mean \pm SD (Range) & \multicolumn{2}{|c|}{$29.2 \pm 6.1(16.2-54.1)$} & \multicolumn{2}{|c|}{$28.4 \pm 5.4(16.7-48.1)$} & $0.159^{*}$ & $1.04(0.99-1.06)$ \\
\hline \multicolumn{7}{|l|}{ BMI Categories* } \\
\hline Low weight & 17 & 10.1 & 27 & 8.3 & \multirow{3}{*}{$0.442^{\S}$} & $1.14(0.59-0.21)$ \\
\hline Eutrophy & 48 & 28.6 & 110 & 34.0 & & $0.79(0.52-1.21)$ \\
\hline Overweight/obesity & 103 & 61.3 & 187 & 57.7 & & 1.0 \\
\hline
\end{tabular}

Eminimum level of significance for bivariate analysis; 95\% Cl: 95\% confidence interval for odds ratio; data showed as n (\%); SD: Standard deviation of the mean; BMl: body mass index; 'Pearson's $\chi^{2}$ test; 'Student's $t$ test for independent groups assuming variance homogeneity; *Student's $t$ test for independent groups assuming variance homogeneity; low weight: BMI < 22; eutrophy: BMI between 22 and 27 ; overweight/obesity: $\mathrm{BMI}>27$ 
Table 3 Functional characteristics of the sample, according to the presence of depressive symptoms.

\begin{tabular}{|c|c|c|c|c|c|c|}
\hline \multirow{2}{*}{ Variables } & \multicolumn{5}{|c|}{ Depressive Symptoms } & \multirow{2}{*}{$\begin{array}{l}\text { Odds Ratio crude } \\
\qquad(95 \% \mathrm{Cl})\end{array}$} \\
\hline & \multicolumn{2}{|c|}{ Yes $(n=180)$} & \multicolumn{2}{|c|}{ No $(n=329)$} & $\mathrm{p}^{\mathrm{E}}$ & \\
\hline \multicolumn{7}{|l|}{ Time to walk $10 \mathrm{~m}$ (s) } \\
\hline Mean \pm SD (Range) & \multicolumn{2}{|c|}{$7.3 \pm 2.3(3.0-16.0)$} & \multicolumn{2}{|c|}{$6.4 \pm 1.8(3.0-20.0)$} & $<0.001^{¥}$ & $1.23(1.14-1.39)$ \\
\hline \multicolumn{7}{|l|}{ Sit-to-stand test* } \\
\hline Mean \pm SD (Range) & \multicolumn{2}{|c|}{$7.6 \pm 2.7(1.0-18.0)$} & \multicolumn{2}{|c|}{$9.3 \pm 3.1(2.0-23.0)$} & $<0.001^{*}$ & $0.81(0.75-0.87)$ \\
\hline \multicolumn{7}{|l|}{ Handgrip strength (Kgf) } \\
\hline Mean \pm SD (Range) & \multicolumn{2}{|c|}{$22.8 \pm 8.9(7.5-46.5)$} & \multicolumn{2}{|c|}{$27.6 \pm 8.6(5.2-21.5)$} & $<0.001^{*}$ & $0.94(0.91-0.96)$ \\
\hline \multicolumn{7}{|c|}{ Katz Index score (points) } \\
\hline Mean \pm SD (Range) & \multicolumn{2}{|c|}{$5.6 \pm 0.8(1.0-6.0)$} & \multicolumn{2}{|c|}{$5.8 \pm 0.5(0.0-6.0)$} & $0.103^{*}$ & $0.55(0.35-1.09)$ \\
\hline \multicolumn{7}{|l|}{ Katz Index categories** } \\
\hline Independent & 164 & 92.1 & 321 & 97.9 & \multirow{2}{*}{$0.002^{\S}$} & 1.0 \\
\hline Dependent & 14 & 7.9 & 7 & 2.1 & & $4.43(1.56-11.03)$ \\
\hline \multicolumn{7}{|l|}{ Pfeffer's scale (points) } \\
\hline Mean \pm SD (Range) & \multicolumn{2}{|c|}{$2.9 \pm 4.3(0.0-23.0)$} & \multicolumn{2}{|c|}{$0.9 \pm 2.6(0.0-26.0)$} & $<0.001^{¥}$ & $1.26(1.15-1.37)$ \\
\hline \multicolumn{7}{|c|}{ Pfeffer's scale categories** } \\
\hline Independent & 137 & 77.4 & 316 & 96.3 & \multirow{2}{*}{$<0.001^{\S}$} & 1.0 \\
\hline Dependent & 40 & 22.6 & 12 & 3.7 & & $3.02(1.84-4.93)$ \\
\hline
\end{tabular}

Eminimum level of significance for bivariate analysis; p: probability; 95\% Cl: 95\% confidence interval; SD: standard deviation of the mean; *data showed as number of times in $30 \mathrm{~s}$; ${ }^{*}$ data showed as $\mathrm{n}(\%) ;{ }^{*}$ Student's $t$ test for independent groups assuming variance homogeneity;

§Pearson's $\chi^{2}$ test.

Table 4 Multivariate binary logistic regression models for predicting the presence of depressive symptoms.

\begin{tabular}{|c|c|c|c|c|}
\hline \multirow{2}{*}{ Independent Variables } & \multicolumn{3}{|c|}{ Regression Coefficient } & \multirow{2}{*}{$\begin{array}{l}\text { Odds Ratio }{ }_{\text {adjustec }} \\
(95 \% \mathrm{Cl})\end{array}$} \\
\hline & $\mathrm{C}_{\text {crude }}$ & S.E. & Sig. & \\
\hline \multicolumn{5}{|l|}{ Initial model ${ }^{* *}$} \\
\hline Women & 0.597 & 0.377 & 0.012 & $1.49(1.18-3.12)$ \\
\hline Illiterate & 1.093 & 0.457 & 0.029 & $2.09(1.32-4.90)$ \\
\hline Low level of education & 0.807 & 0.415 & 0.037 & $1.74(1.15-2.98)$ \\
\hline Lower score for the sit-to-stand test* & -0.116 & 0.047 & 0.014 & $0.89(0.81-0.98)$ \\
\hline Lower handgrip strength & -0.051 & 0.021 & 0.016 & $0.95(0.91-0.99)$ \\
\hline Dependence in IADLs (Pfeffer's scale) & 1.347 & 0.457 & 0.002 & 4.00 (1.18-9.79) \\
\hline \multicolumn{5}{|l|}{ Final model ${ }^{* * *}$} \\
\hline Women & 1.597 & 0.412 & 0.012 & $2.87(1.92-9.23)$ \\
\hline Illiterate & 1.758 & 0.446 & 0.009 & $2.13(1.89-5.12)$ \\
\hline Low level of education & 0.809 & 0.407 & 0.039 & $1.23(1.05-2.74)$ \\
\hline Lower score on the sit-to-stand test* & -0.118 & 0.041 & 0.004 & $0.89(0.82-0.96)$ \\
\hline Lower handgrip strength & -0.048 & 0.014 & $<0.001$ & $0.95(0.93-0.98)$ \\
\hline Dependence in IADLS (Pfeffer's scale) & 1.392 & 0.445 & 0.002 & $4.03(1.68-9.64)$ \\
\hline
\end{tabular}

95\% Cl: 95\% confidence interval; $C_{\text {crude }}$ : crude regression coefficient; S.E.: standard error for the regression coefficient; Sig.: $p=$ minimum significance level for the regression coefficient; ${ }^{*}$ sit-to-stand test: number of repetitions in $30 \mathrm{~s}$; IADLs: Instrumental Activities of Daily Living; ${ }^{*}$ initial model: Nagelkerke $\mathrm{R}^{2}=0.354$; Hosmer-Lemeshow test $\left(\chi^{2}=11.130 ; \mathrm{p}=0.633\right)$; Cox \& Snell $=0.288$; general rate of correct answers - confusion matrix $=55.7 \%$; ${ }^{* * *}$ final model: Nagelkerke $R^{2}=0.422$; Hosmer-Lemeshow test $\left(x^{2}=6.866 ; p=0.822\right) ;$ Cox $\&$ Snell $=0.388$; general rate of correct answers - confusion matrix $=72.4 \%$. 
manifest DS than men, and illiteracy in the sample is compatible with municipal indices, indicating that $41.3 \%$ of the older population have little or no education. Only in 2 health districts (Restinga and Lomba do Pinheiro) the number of uneducated men was higher than women. ${ }^{17}$

Illiteracy and low level of education were important factors in older adults with DS. Illiteracy can hinder the social participation of older persons, making them lonelier and diminishing social support. ${ }^{19}$ Limitations on IADLs and restricted choice of hobbies are common characteristics of those who are totally illiterate, making them more dependent on a support network and susceptible to the diagnosis of severe depression. ${ }^{18}$

This result - association between DS and low level of education or illiteracy - is important to understand the difficulties of this population in accessing and using the health care system, as well as in understanding information from health care professionals and managing their self-care. ${ }^{20}$

Participants with DS in this study also presented worse functional characteristics, such as longer time to walk $10 \mathrm{~m}$, fewer repetitions in the sit-to-stand test, and poorer performance on the HGS test, indicating that functionally, the participants with DS presented decreased strength and agility.

The decrease in gait speed was another aspect found in this research that has been pointed out as a strong predictor of long-term DS in the older population. In addition, regardless of associated comorbidities, this aspect has been incorporated into the depressive syndrome due to its importance. ${ }^{21}$

Despite having found a significant association between lower gait speed and DS for women, a cohort study found gait speed as a predictor of depression among men, ${ }^{22}$ making the sex variable an important factor to consider in this relationship.

There may be a bidirectional character in the relationship between DS and gait speed. That is, regardless of which occurs first, a proper management of both factors is possible to prevent future suffering from both mental and functional causes. ${ }^{23}$

Poor performance in the sit-to-stand test for lower limb strength assessment has also been associated with the presence of DS. Older men who were previously diagnosed with depression performed worse on the sit-to-stand test and the Timed Up and Go Test (TUG), 9 years after the diagnosis of depression, compared with those who never had depression. ${ }^{24}$

The relationship between DS and worse sit-to-stand test scores seems to be an important factor in other populations. In institutionalized older adults, those with lower scores in the sit-to-stand test showed higher scores in DS measurements. ${ }^{25}$

Another study of older adults involving depression and functionality found that poor performance in the sit-to-stand test was a stronger predictor of depression in women, while poorer gait speed performance was a better predictor of depression in men. ${ }^{26}$ This same study pointed out that, although it has a significant relationship with DS, HGS proved to be a less important predictor in this study. ${ }^{26}$ Changing the values measured would not necessarily cause changes in DS, possibly due to a psychological adaptation that occurred in the aging process. ${ }^{27}$

Another research with community-dwelling older people points to a significant association between HGS and depression, but this association was observed only in individuals who have concomitant decreased muscle strength (measured by dynamometry) and mobility (assessed by gait speed). This finding reinforces the hypothesis that functionality should be measured by various instruments. ${ }^{28}$

In a recent systematic review, we confirmed the scarcity of studies regarding the identification of HGS as a predictor of depression. Initially, only 1 investigation seeking this association was found, however this is due to the inclusion of longitudinal studies only. ${ }^{29}$

A cross-sectional study with a population similar to that in the present study found an equivalent result in the association between depression and HGS with depressed older people with lower scores compared to non-depressive ones. ${ }^{30}$ However, another study makes an important caveat, indicating sarcopenia as a possible confounding factor in the relationship between HGS and depression, as it shares the same pathophysiological pathway as depression. ${ }^{31}$

In addition, these characteristics end up impacting other aspects of the lives of the individuals affected by them. This is the case of the worse performance also in the IADLs measured by the Pfeffer scale, ${ }^{32}$ which indicates that older people with DS who have activity limitations caused by loss of bodily functions also suffer from restrictions on their participation in real-life situations outside their homes. ${ }^{33}$

A cohort study of US older adults investigated the association of depression with loss of ADL / IADL skills according to race and sociodemographic characteristics over an 8-year period. Results indicated positive association in both racial groups, white and black. However, white older people showed progression of depression-related ADL disabilities over time, while black older people did not. ${ }^{34}$ 
The inability to perform ADLs was significant when associated with depression in a study with English aging adults. This relationship was also stronger in women who were older, had lower income, presented 2 or more comorbidities, and who did not live with a partner. ${ }^{35}$

The results related to the association of DS with worse functional performance are frequent in older people living in the community around the world, corroborating with those found in the present study. 36,37

An association with frailty syndrome was also identified, as reported by Fried et al., who studied AfricanAmerican women with low level of education, low income, lower functionality, more comorbidities and chronic diseases. These data suggest that older women are more susceptible to falls, with worsen performance in ADLs and IADLs, reduced mobility, and high mortality. The authors observed that these women presented DS because they fit the frailty criteria. ${ }^{12}$

Except for sex, all factors investigated and identified as predictors of DS are modifiable not only through drug therapy but also by simple strategies and methods, easily applicable in primary care settings, such as respect for the individual's religion and spirituality - to improve the care of those with anxiety and depression - group physical activity, psychotherapy, electronic games, among others. ${ }^{33,38-41}$

The cross-sectional design of the present study (with only 1 measurement point) is a limitation, because the direction of the causal relationship between DS and risk factors cannot be determined, since this association can also be bidirectional. ${ }^{23}$ Another point to be emphasized is that the older adults excluded from the sample were possibly much more fragile and had greater impairments in functional and cognitive capacity than those taken to the collection site. Despite these limitations, it is important to highlight the representativeness of the investigated sample, of sufficient size for a prevalence study, selected randomly and proportionally in all health care districts of the municipality, which may have reduced the selection bias.

The data reported in the present study can be used to plan actions and strategies that favor health promotion in this population, already weakened by aging and low education, among other unfavorable aspects.

\section{CONCLUSION}

In a sample with a high prevalence of DS, despite the predominance of older people without DS, it was concluded that women with low level of education, illiterate, and with difficulty in IADLs should be investigated for the presence of DS, since they were identified as a risk group for the development of such symptoms.

\section{CONFLICT OF INTERESTS}

There is no conflict of interest to declare.

\section{ACKNOWLEDGEMENTS}

We thank the study participants and their families as well as the FHS teams from Porto Alegre.

\section{FINANCING}

The EMISUS base research received financial support from the Rio Grande do Sul State Research Support Foundation (FAPERGS), through Public Notice 02/2009, of the Research Program for the Unified Health System (PPSUS), under n. 09/0075 -7 and n. 09 / 0055-0.

\section{REFERENCES}

1. Simões CCS. Relações entre as alterações históricas na dinâmica demográfica brasileira e os impactos decorrentes do processo de envelhecimento da população [Internet]. Rio de Janeiro: IBGE, Coordenação de População e Indicadores Sociais; 2016 [acessado em 16 ago. 2019]. 119 p. Disponível em: http://biblioteca.ibge.gov. br/visualizacao/livros/liv98579.pdf

2. Instituto Brasileiro de Geografia e Estatística. Síntese de indicadores sociais uma análise das condições de vida da população brasileira 2014 [Internet]. Rio de Janeiro: Instituto Brasileiro de Geografia e Estatística; 2015 [acessado em 20 ago. 2019]. 214 p. Disponível em: https://biblioteca.ibge.gov.br/visualizacao/livros/liv95011.pdf
3. Instituto Brasileiro de Geografia e Estatística. Pesquisa nacional de saúde 2013: ciclos de vida: Brasil e grandes regiões [Internet]. Rio de Janeiro: Instituto Brasileiro de Geografia e Estatística; 2015 [acessado em 15 set. 2019]. 85 p. Disponível em: https://biblioteca.ibge.gov.br/ visualizacao/livros/liv94522.pdf

4. Sartor-Glittenberg C, Lehmann S, Okada M, Rosen D, Brewer K, Bay RC. Variables Explaining Health-Related Quality of Life in Community-Dwelling Older Adults. J Geriatr Phys Ther [Internet] 2014 [acessado em 3 out. 2019];37(2):83-91. Disponível em: https:// insights.ovid.com/pubmed?pmid=23959246. http://doi.org/10.1519/ JPT.0b013e3182a4791b 
5. Brasil. Ministério da Saúde. Secretaria de Atenção à Saúde. Departamento de Atenção Básica. Envelhecimento e saúde da pessoa idosa. Brasília: Ministério da Saúde; 2007.

6. Adams TR, Rabin LA, Da Silva VG, Katz MJ, Fogel J, Lipton RB. Social support buffers the impact of depressive symptoms on life satisfaction in old age. Clin Gerontol [Internet]. 2016 [acessado em 28 set. 2019];39(2):139-57. Disponível em: https://www.tandfonline. com/doi/full/10.1080/07317115.2015.1073823. https://doi.org/10. 1080/07317115.2015.1073823

7. Rabelo DF, Neri AL. Avaliação das Relações Familiares por Idosos com Diferentes Condições Sociodemograficas e de Saúde. Psico-USF [Internet]. 2016 [acessado em 10 out. 2019];21(3):663-75. Disponível em: http://www.scielo.br/pdf/pusf/v21n3/2175-3563-pusf-21-03-00663. pdf. http://dx.doi.org/10.1590/1413-82712016210318

8. World Health Organization. Depression and Other Common Mental Disorders: Global Health Estimates. Genebra: World Health Organization; 2017.

9. Gomes I, Nogueira EL, Engroff P, Ely LS, Schwanke CHA, De Carli GA, et al. The multidimensional study of the elderly in the Family Health Strategy in Porto Alegre, Brazil (EMI-SUS). PAJAR [Internet]. 2013 [acessado em 30 set. 2019];1(1):20-4. Disponível em: http://revistaseletronicas. pucrs.br/ojs/index.php/pajar/article/view/15792/10402

10. Lipschitz DA. Screening for nutritional status in the elderly. Prim Care. 1994;21(1):55-67.

11. Jones CJ, Rikli RE, Beam WC. A 30-s Chair-Stand Test as a Measure of Lower Body Strength in Community-Residing Older Adults. Res Q Exerc Sport [Internet]. 1999 [acessado em 3 out. 2019];70(2):113-9. Disponível em: https://www.ncbi.nlm.nih.gov/pubmed/10380242. https://doi.org/10.1080/02701367.1999.10608028

12. Fried LP, Tangen CM, Walston J, Newman AB, Hirsch C, Gottdiener $J$, et al. Frailty in Older Adults: Evidence for a Phenotype. J Gerontol A Biol Sci Med Sci [Internet]. 2001 [acesado em 3 out. 2019];56(3):M146-M157. Disponível em: https://academic.oup.com/ biomedgerontology/search-results?page $=1 \& q=$ Frailty\%20in\%20 Older\%20Adults\%3A\%20Evidence\%20for\%20a\%20Phenotype\&fl_ SitelD=5306\&SearchSourceType=1\&allJournals=1. https://doi. org/10.1093/gerona/56.3.M146

13. Middleton A, Fritz SL, Lusardi M. Walking Speed: The Functional Vital Sign. J Aging Phys Act [Internet] 2015 [acessado em 3 out. 2019];23(2):314-22. Disponivel em: https://www.ncbi.nlm.nih.gov/pmc/articles/PMC4254896/ pdf/nihms642780.pdf. https://doi.org/10.1123/japa.2013-0236

14. Katz S, Ford AB, Moskowitz RW, Jackson BA, Jaffe MW. Studies of illness in the aged. The index of ADL: a standardized measure of biological and psychosocial function. JAMA [Internet] 1963 [acessado em 3 out. 2019];185(12):914-9. Disponível em: https://jamanetwork. com/journals/jama/article-abstract/666768. https://doi.org/10.1001/ jama.1963.03060120024016

15. Pfeffer RI, Kurosaki TT, Harrah CH, Chance JM, Filos S. Measurement of functional activities in older adults in the community. J Gerontol [Internet]. 1982 [acessado em 3 out. 2019];37(3):323-9. Disponível em: https://academic.oup.com/geronj/article-abstract/37/3/323/6110 05? redirectedFrom=fulltext. https://doi.org/10.1093/geronj/37.3.323

16. Almeida OP, Almeida SA. Confiabilidade da versão brasileira da Escala de Depressão em Geriatria (GDS) versão reduzida. Arq Neuropsiquiatr [Internet]. 1999 [acessado 3 out. 2019];57(2-B):421-6. Disponível em: http://www.scielo.br/pdf/anp/v57n2B/1446.pdf

17. Prefeitura de Porto Alegre. Secretaria Adjunta do Idoso. Plano Municipal da Pessoa Idosa de Porto Alegre: 2016 a 2018 [Internet]. Porto Alegre: Gabinete de Comunicação Social/PMPA; 2015 [acessado em 15 set. 2019]. Disponível em: http://lproweb.procempa.com.br/pmpa/prefpoa/ observatorio/usu_doc/plano_municipal_da_pessoa_idosa_de_porto_ alegre_-_miolo_210x297mm_[completo_-_corrigido_2].pdf

18. Kim BS, Lee DW, Bae JN, Chang SM, Kim S, Kim KW, et al. Impact of illiteracy on depression symptomatology in community-dwelling older adults. Int Psychogeriatr [Internet]. 2014 [acessado em 3 out. 2019];26(10):1669-78. Disponível em: https:/www.cambridge.org/core/journals/internationalpsychogeriatrics/article/impact-of-illiteracy-on-depression-symptomatology-incommunitydwelling-older-adults/C27F1CEOFF1B6916FB70E1F5A30044FO\#. https://doi.org/10.1017/S1041610214001094

19. Olagunju AT, Olutoki MO, Ogunnubi OP, Adeyemi JD. Late-life depression: Burden, severity and relationship with social support dimensions in a West African community. Arch Gerontol Geriatr [Internet]. 2015 [acessado em 3 out. 2019];61(2):240-6. Disponível em: https://www. sciencedirect.com/science/article/abs/pii/S0167494315000710. https://doi.org/10.1016/j.archger.2015.05.002
20. Serper M, Patzer RE, Curtis LM, Smith SG, O'Conor R, Baker DW, et al. Health Literacy, Cognitive Ability, and Functional Health Status among Older Adults. Health Serv Res [Internet] 2014 [acessado em 3 out. 2019];49(4):1249-67. Disponível em: https://www.ncbi.nlm. nih.gov/pmc/articles/PMC4111764/pdf/hesr0049-1249.pdf. https:// doi.org/10.1111/1475-6773.12154

21. Sanders JB, Bremmer MA, Comijs HC, Deeg DJH, Beekman ATF. Gait Speed and the Natural Course of Depressive Symptoms in Late Life; An Independent Association With Chronicity? J Am Med Dir Assoc [Internet]. 2016 [acessado em 3 out. 2019];17:331-5. Disponível em: https://www.jamda.com/article/S1525-8610(15)00727-6/pdf. http://dx.doi.org/10.1016/j.jamda.2015.11.016

22. Sanders JB, Bremmer MA, Deeg DJ, Beekman AT. Do depressive symptoms and gait speed impairment predict each other's incidence? A 16-year prospective study in the community. J Am Geriatr Soc [Internet]. 2012 [ acessado em 3 out. 2019];60(9):1673-80. Disponível em: https://doi.org/10.1111/j.1532-5415.2012.04114.x

23. Demakakos P, Cooper R, Hamer M, de Oliveira C, Hardy R, Breeze E. The Bidirectional Association between Depressive Symptoms and Gait Speed: Evidence from the English Longitudinal Study of Ageing (ELSA). PLoS One [Internet]. 2013 [acessado em 3 out. 2019];8(7):e68632. Disponível em: https://journals.plos.org/plosone/article/file?id=10.1371/ journal.pone.0068632\&type=printable

24. Almeida OP, Hankey GJ, Yeap BB, Golledge J, Hill KD, Flicker L. Depression Among Nonfrail Old Men Is Associated With Reduced Physical Function and Functional Capacity After 9 Years Follow-up: The Health in Men Cohort Study. J Am Med Dir Assoc [Internet]. 2017 [acessado em 3 out. 2019];18(1):65-9. Disponível em: https:// www.jamda.com/article/S1525-8610(16)30401-7/pdf. https://doi. org/10.1016/j.jamda.2016.09.002

25. Kvæl LAH, Bergland A, Telenius EW. Associations between physical function and depression in nursing home residents with mild and moderate dementia: a cross-sectional study. BMJ Open [Internet] 2017 [acessado em 3 out. 2019];7:e016875. Disponivel em: https:// bmjopen.bmj.com/content/bmjopen/7/7/e016875.full.pdf. https://doi. org/10.1136/ bmjopen-2017-016875

26. Veronese N, Stubbs B, Trevisan C, Bolzetta F, De Rui M, Solmi M, et al. Poor Physical Performance Predicts Future Onset of Depression in Elderly People: Pro. VA Longitudinal Study. Phys Ther [Internet] 2017 [acessado em 3 out. 2019];97(6):659-68. Disponível em: https://academic.oup.com/ptj/article/97/6/659/2996751. https://doi. org/10.1093/ptj/pzx017

27. Taekema DG, Gussekloo J, Maier AB, Westendorp RG, de Craen AJ. Handgrip strength as a predictor of functional, psychological and social health. A prospective population-based study among the oldest old. Age Ageing [Internet]. 2010 [acessado em 3 out. 2019];39(3):331-7. Disponível em: https://academic.oup. com/ageing/article/39/3/331/41128. https://doi.org/10.1093/ ageing/afq022

28. Vasconcelos KSS, Dias JD, Bastone AC, Vieira RA, Andrade ACS, Perracini MR, et al. Handgrip strength cutoff points to identify mobility limitation in community-dwelling older people and associated factors. J Nutr Health Aging [Internet]. 2016 [acessado em 3 out. 2019];20(3):306-15. Disponível em: https://link.springer. com/article/10.1007/s12603-015-0584-y. https://doi.org/10.1007/ s12603-015-0584-y

29. Rijk JM, Roos PR, Deckx L, Akker M, Buntinx F. Prognostic value of handgrip strength in people aged 60 years and older: A systematic review and meta-analysis. Geriatr Gerontol Int [Internet]. 2016 [acessado em 3 out. 2019];16(1):5-20. Disponível em: https://onlinelibrary.wiley. com/doi/epdf/10.1111/ggi.12508. https://doi.org/10.1111/ggi.12508

30. Lino VTS, Rodrigues NCP, O'Dwyer G, Andrade MKN, Mattos IE, Portela MC. Handgrip Strength and Factors Associated in Poor Elderly Assisted at a Primary Care Unit in Rio de Janeiro, Brazil. PLoS One [Internet] 2016 [acessado em 3 out. 2019];11(11):e0166373. Disponível em: https://journals.plos.org/plosone/article/file?id=10.1371/journal. pone.0166373\&type=printable. https://doi.org/10.1371/journal. pone. 0166373

31. Pasco JA, Williams LJ, Jacka FN, Stupka N, Brennan-Olsen SL, Holloway KL, et al. Sarcopenia and the Common Mental Disorders: a Potential Regulatory Role of Skeletal Muscle on Brain Function? Curr Osteoporos Rep [Internet]. 2015 [acessado em 3 out. 2019];13(5):351-7. Disponível em: https://link.springer.com/content/pdf/10.1007\%2Fs11914-0150279-7.pdf. https://doi.org/10.1007/s11914-015-0279-7 
32. Connolly D, Garvey J, McKee G. Factors associated with ADL/ADL disability in community dwelling older adults in the Irish longitudinal study on ageing (TILDA). Disabil Rehabil [Internet]. 2017 [acessado em 3 out. 2019];39(8):809-16. Disponível em: https://www.tandfonline.com/doi/ full/10.3109/09638288.2016.1161848?scroll=top\&needAccess=true. https://doi.org/10.3109/09638288.2016.1161848

33. Organização Mundial da Saúde. CIF: Classificação Internacional de Funcionalidade, Incapacidade e Saúde. São Paulo: Editora da Universidade de São Paulo; 2003.

34. Rajan KB, Barnes LL, Wilson RS, Evans DA, Mendes de Leon CF Racial Differences on Association of Depressive Symptoms With Combined Basic and Instrumental Activities of Daily Living. J Gerontol A Biol Sci Med Sci [Internet]. 2014 [acessado em 3 out 2019];69(2):215-22. Disponível em: https://www.ncbi.nlm.nih.gov/ pmc/articles/PMC4048984/pdf/glt074.pdf. http://doi.org/10.1093/ gerona/glt074

35. Torres JL, Lima-Costa MF, Marmot M, de Oliveira C. Wealth and Disability in Later Life: The English Longitudinal Study of Ageing (ELSA). PLoS One [Internet]. 2016 [acessado em 3 out. 2019];11(11):e0166825. Disponivel em: https://journals.plos.org/plosone/article/file?id=10.1371/ journal.pone.0166825\&type=printable. http://doi.org/10.1371/journal. pone.0166825

36. Sivertsen H, Bjørkløf GH, Engedal K, Selbæk G, Helvik AS. Depression and Quality of Life in Older Persons: A Review. Dement Geriatr Cogn Disord [Internet]. 2015 [acessado em 3 out. 2019];40:311-39. Disponível em: https://www.karger.com/Article/Pdf/437299. http:// dx.doi.org/10.1159\%2F000437299
37. Weyerer S, Eifflaender-Gorfer S, Köhler L, Jensen F, Maier W, Fuchs A, et al. Prevalence and risk factors for depression in non-demented primary care attenders aged 75 years and older. J Affect Disord [Internet]. 2008 [acessado em 3 out. 2019];111(2-3):153-63. Disponível em: https:// www.sciencedirect.com/science/article/pii/S016503270800092X. https://doi.org/10.1016/j.jad.2008.02.008

38. Phillips LL, Paukert AL, Stanley MA, Kunik ME. Incorporating religion and spirituality to improve care for anxiety and depression in older adults. Geriatrics. 2009;64(8):15-8.

39. Chi I, Jordan-Marsh M, Guo M, Xie B, Bai Z. Tai chi and reduction of depressive symptoms for older adults: a meta-analysis of randomized trials. Geriatr Gerontol Int [Internet]. 2013 [acessado em 3 out. 2019];13(1):3-12. Disponível em: https://doi.org/10.1111/j.1447-0594.2012.00882.x

40. Jonsson U, Bertilsson G, Allard P, Gyllensvärd H, Söderlund A, Tham A, et al. Psychological Treatment of Depression in People Aged 65 Years and Over: A Systematic Review of Efficacy, Safety, and Cost-Effectiveness. PLoS One [Internet]. 2016 [acessado em 3 out. 2019];11(8):e0160859. Disponível em: https://journals.plos.org/plosone/ article/file?id=10.1371/journal.pone.0160859\&type=printable. https:// doi.org/10.1371/journal.pone.0160859

41. Chao YY, Scherer YK, Montgomery CA. Effects of using Nintendo $\mathrm{Wii}^{\mathrm{TM}}$ exergames in older adults: a review of the literature. J Aging Health [Internet]. 2015 [acessado em 3 out. 2019];27(3):379-402. Disponível em: https://journals.sagepub.com/doi/abs/10.1177/089 8264314551171 ?rfr dat=cr_pub\%3Dpubmed\&url ver=739.882003\&rfr_id=ori\%3Arid\%3Acrossref.org\&journalCode=jaha. https:// doi.org/10.1177\%2F0898264314551171 